\title{
What is Theocratic Democracy: a Case Study of Iranian Political System
}

\author{
Syed Raheem Abbas ${ }^{\mathrm{a}}$ and Muhammad Asim ${ }^{\mathrm{b} *}$ \\ ${ }^{a}$ College Bhakkar \\ Pakistan \\ ${ }^{b}$ College Asghar Mall, Rawalpindi \\ Pakistan
}

Received 13.11.2014, received in revised form 13.01.2015, accepted 16.02.2015

Democracy is a preferred and famous political mode of governing the society in all over the world. It has several types according to the nature and environment of the demography. In theocratic societies, democracy is really a debatable issue. As Europe had experienced serious role of Church, Muslims were still demanding for governing under Islamic rules. But, the problem is, every sect define its own Islamic Political System.

This article presented definition and history of the democracy, its types and its role in the theocratic societies. Christian and Muslim societies are also discussed here. Iranian political system which is a modern democratic system under the theocratic structure is a case study of this article which is working successfully since the Revolution of 1979.

Keywords: Shura, Rehbar-e-Muazam, Sunnah, Shariah.

Research area: politology.

\section{Hypothesis}

Iranian political system is a successful governing system which is totally relevant to the Quran and Sunnah, and not only acceptable for Muslims theocratic societies but it can be practiced in any theocratic society in all over the world.

\section{Research Methodology}

This research is based on historical descriptive, analytical, comparative and qualitative methods. The data is collected from books, research journals, news papers, internet, interviews, results of different dissertations, and personal visit of Iran in which attending several seminars, workshops and training classes including visiting several universities and Research Centers in Qom and Tehran.

\section{Introduction}

Everyone takes the meaning of democracy in his own way and perception. Similarly, multiple questions are raised about the real implication of the concept of democracy. What are the required elements that would enable its popular system of the day? And what are the required activities that would help to consolidate such a form of government? What are the advantages, where

(C) Siberian Federal University. All rights reserved

* Corresponding author E-mail address: raheemabbas786@gmail.com, asimsheikh62@yahoo.com 
are the weaknesses? And what are the strong and affecting areas of such a form of government?

Now here will be discussed that how various scholars have defined democracy: Given by Abraham Lincoln, "The government of the people, by the people and for the people".(Haque, 1994, p. 292)

In other words, we can say that democracy is such form of government which comes from the people; exercised by the people, and for people's own interests.

Democracy is a system of government in which people decide issues as a group. This system of government is taken as the form of government in which all the masses have weight of their opinion. The canons of this approach are so comprehensive one that these are equally applicable to all other bodies and institutions alike. In a democracy, all the matters are run after the people's fair-will and the government necessarily accepts those decisions taken by the people. The roots of democracy can be traced back from the ancient Greece.(K.Rai, 2000, p. 412)

According to Prof. Seely; "Democracy provides a form of government in which there is every citizen's participation in the government affairs”.(Haque, 1994, p. 292)

Lord Bryce says that "In a democratic government the rights to rule does not belong to any specific class, rather all individuals of the society share this power collectively. (Mouhammad, 1994, p. 147)

Dicey defines democracy thus; "the form of the government in which the government body is comparatively a large fraction of the entire nation”.(Dr.Anup Kumar, 1985, p. 188)

Gettle defines it as that "the form of government in which the mass of the population possesses the right to share in the exercise of sovereign power."(K.Rai, 2000, p. 412)

According to President F.D. Roosevelt; "Democracy was not mere a matter of universal suffrage and unhampered expression of the popular will. It must be a positive and constructive force in the daily lives of the people and provide not merely for political but economic needs also, if men were forced to choose between liberty and bread.”(Dr.Anup Kumar, 1985, p. 188)

Robert Dahl says that there are institutional guarantees that must be present before the citizenry can be said to be living in a democracy. These are:

- Freedom to form and join organizations

- Freedom of expression

- The right to vote

- Eligibility for public office

- The right of political leaders to compete for support and votes

- Alternative sources of information

- Free and fair elections

- Institutions for making government policies depend on votes and other expressions of preference.(Robert, 2000, p. 07)

\section{History of democracy}

Western political philosophers trace their political heritage back to Greek history, with Plato b. 437 B. C and Aristotle b. 384 B.C as the two main contributors of that period. Western writers derive the term democracy from the ancient Greeks. In Greek, demons mean people and keratin means to rule. Therefore, democracy means people's power or rule of the people. This literal meaning of the term democracy is the definition of it. Democracy in Greece, as it was practiced in Athens in the 4th century B.C., was based in the direct participation of the people who decided their collective affairs in town meetings. Each citizen was directly in evolved in the government. Abraham Lincoln seemed to be influenced by Greek democracy when he said, "Democracy is people" Lincoln's formula cannot be applied to modern democracy, because 
modern democracy is representative and not a direct democracy, whereas Greek democracy was a direct democracy. (Chany, 2011, p. 143)

The word 'democracy' is a term which has been derived from the two Greek words 'demos' and 'keratin'; demos means 'People' and keratin means 'to rule or govern'. So democracy can then literally be defined as: "The government of the people or government of the majority. Democracy, as a state form, is to be famous than monarchy, aristocracy and dictatorship. We are well aware of the most common definition of democracy.

There are two major types of democracy, direct and indirect democracy.

\section{Direct Democracy}

When the people can directly express their will on public matters in a mass assembly rather than through their representatives is called direct or pure democracy. It was a participatory democracy. The direct democracy is suitable for the states that are small in area and population. It is then physically possible for the people to assemble in amass meeting to make laws, decide policies, elect public officials and settle other problems.(Muhammad, 1994, p. 203)

Garner defines direct democracy as "a form of government in which the will of the state is directly or immediately expressed through the people"(Haque, 1994, p. 293)

All the people assemble together in a mass meeting as often as required, where in them directly take decisions on issues of governance and devise laws regarding the same. The type of democracy which overcame in the Greek citystates was pure or direct democracy. All the freemen used to meet together in general assemblies, passed laws and executed those one, received the ambassadors and acted as jurymen. This type of democracy was revived later on in the medieval times by Italian city-states. In the modern world, the system of direct democracy is observed in
Switzerland in the form of the popular legislature that overwhelms in four Cantons of the country, viz., Appenzell, Uri, Unterwalden and Glarus. On a Sunday, in April or May, the adult male citizens assemble in the Canton to consider the governmental affairs. In these meetings, new laws are made with the mutual agreements and the old ones are altered, taxes are levied, budgets are adopted and officials are chosen according to the Cantons and the constitution.(Haque, 1994, p. 293)

Modern direct democracy is experienced by different means. Referendum is one of those means. Referendum is a vote through which the people entitled to vote can express a view on a particular issue of public policy. Switzerland still exercises popular control over the government through referendum.(Muhammad, 1994, p. 293)

\section{Indirect Democracy}

Under representative or indirect democracy, people elect their representatives to rule who take decisions on their behalf. Accordingly, the existing system of democracy in most countries is indirect or representative democracy. In other words, the liability of taking decisions on public affairs and issues of government and administration, and similarly, framing laws rests not with the people themselves but also with their representatives. The representatives are elected periodically by the masses. For this purpose elections take place in democracies in certain intervals. In the UK and India, general elections occur after every five years and in USA after four years. In both the UK and India, the representatives are designated as Members of Parliament.

John Stuart Mill defines indirect or representative democracy as one in which; "the whole people or some numerous portions of them, exercise the governing power through deputies periodically elected by them"(Haque, 1994, p. 294) 


\section{Model of Democracy}

Now we have to discuss about the some important model of democracy, such as western Democracy, protectivedemocracy, Consociational democracy, legal democracy, socialist democracy, inclusive democracy, pluralist democracy, liberal democracy, theocratic democracy, difference $\mathrm{b} / \mathrm{w}$ theocracy and Theo democracy, Islamic democracy and Iranian democracy.

\section{State, Church and Theocracy}

Christianity played an important role in the Western political legacy. The efficient spread of Christianity began with the ministry of St. Paul, and during his lifetime Christianity confronted the Roman Empire. In the beginning, Christians were tortured and persecute. Later, between (324, 327) A.D Constantine the Great himself adopted the Christian faith and made Christianity the official religion of the Roman Empire.(W.Y.Elliot, 1949, p. 289)

Christianity flourished after the Roman Empire was divided in two East and West with both having strong institution churches. In the beginning, the Roman Catholic Church in the West was simple.

Strong bishops such as Augustine and administration; Later, the leadership of the Church began to center on the Bishop of Rome, and finally he was familiar as chief hierarchical officer in the Church and was called the Papa the pope.(Ismeal, 1991, p. 67)

Why the Church emerged independently and why both spiritual and political authority did not unite in the person of the pope might have many answers. First, it is said that a strong tradition of civil rule was innate from Rome, and it resisted any move that would change the status quo. Second, they were not always strong Popes were weak and unable to control the political affairs of Europe. Third, the Church paying attention on the spiritual side of Christianity more than of time; therefore, it did not present any significant form of government.

The separate development of the Church in Christianity became the manifestation of Jesus Christ on earth, and the Pole derived his authority directly from Christ. Here the doctrine of the "Two Swords" emerged. It was believed that the Pole was entrusted with two swords. The one he kept was gladiu spirituals, the other, the gladiu temporal is, was given to worldly leaders who were to use its authority according to instructions provided by the Pope. This gave birth to the theory of a temporal/spiritual relationship. There temporal rulers had no unique authority but derived it directly from the Pole and indirectly from Christ.(Ross, 1952, p. 13)

Unluckily, this theory eventually gave birth to a power struggle. Although it worked during the reign of the Emperor Charlemagne, after his death there were increasing controversies between the Pole and following Emperors. The Pope wanted the Emperor to consult him in all important affairs of state. The Emperor did not want intervention in political affairs of his Empire. The history of the Holy Roman Empire with the struggle between Church and state are the history of lengthy and bitter disputes which dominated the early medieval history of the European world. The Pope Emperor struggle for political dominance led to the decline of the Holy Roman Empire and made possible the emergence of national kings.(F.Gaus, 2000, p. 211)

\section{Theocratic Democracy}

The term "theocracy" derived from the Greek word theocratic, which is a compound word that combines Theo's, which means "god," and keratin, which means "to rule." A theocracy, therefore, is a form of government in which a religious leader rules according to a certain religious belief. 
And in theocratic democracy the head of the government may also be the head of a specific religion as in the case of Vatican City. Theocratic rulers are guided specifically by their religious beliefs and might see themselves as messengers of their god who are meant to rule their people. (Peterson, 2007, p. 15)

The term theocracy signifies belief in governance by divine. The concept of theocracy was first coined by the Jewish historian Flavius Josephus (37 CE-c. 100 CE). In Gentile, attempting to explain to organization and political system of the Jewish commonwealth of his time, Josephus compared theocracy with other forms of government, such as monarchy, oligarchy, and republics said:

"Our legislator (Moses) had no regard to any of these forms, but he ordained our government to be what, by a strained expression, may be termed a theocracy], by ascribing the authority and power to God, and by persuading all the people to have a regard to him, as the author of all good things." (Micel, 2003, p. 12)

Few concepts have changed more radically over time than the concept of theocracy. According to its oldest meaning, as used by Josephus, the implication is not that ministers assumed political power.

However, according to the more modern definition theocracy is, "a system of government by sacerdotal order, claiming divine commission." a state in which priests exercise political powers or more precisely a state ruled by the ministers. Theocratic forms of government have existed throughout history. Theocracies were known among ancient people, as in Egypt and Tibet, where kings represented and even personified the divinity.

Theocracy is a government ruled by a religious authority, where religious beliefs are the basis of government. There are many governments in which leaders claim to be inspired by God, or claim to obey the will of God. This does not make a government a theocracy. What makes a government a theocracy is when lawmakers actually believe that leaders are governed by the will of God?

Iran and Saudi Arabia are often mentioned as modern examples of theocratic governments. In practice, North Korea also resembles a theocracy due to the supernatural powers attributed to Kim Jong-Il; and the comparable respect he receives from other government officials, the military; and the hundreds of thousands of indoctrination centers that center on devotion to his will and legacy. There are theocratic movements virtually every in country on Earth, but true modern theocracies are mainly found in the Muslim world.

\section{Democratic Theocracy}

Theocracy is a type of government that is ruled by a religious authority and such government is totally based on religious beliefs.

A democratic theocracy means combining parts of both types of government. Power is shared between representatives elected by the peoples and the religious leaders. But religious leaders have more power than the government.

\section{Islamic Democracy}

Universal commitment to the idea democracy is new and rose up in twentieth century. Democracy is a method which lacks fixed, unalterable moral and philosophical ideas and values. But in order to establish a political democratic regime, there must be some criteria. A democratic political system should provide the opportunity for the people to participate, to express their ideas, orientations and needs, to distribute political power through free elections and be able to regulate the governors. (Voll, 2006, p. 32) 
These political rights and duties of the people could be dealt with a fixed framework consisting of specific rights and values. In current limited democracies these frameworks are embodied in constitutions, and constitutions in turn are influenced by values and beliefs that people of each country respect and support. Muslim advocates of democracy cannot accept 'pure democracy' as Abu Al-Mawardi says:

"Islam is not democracy: for democracy is the name given to that particular form of government in which dominion finally rests with the people, in which legislation depends both in its form and content on the force and direction of public opinion and laws are modified and altered, to correspond to changes in that opinion."

Therefore the key issue concerning religious democracy is whether Islam has the capacity to draw an appropriate framework for a democratic government that meets the above-mentioned criteria. Many Islamic thinkers believe that Islam has assigned significant political as well as social roles and duties to Muslims. In Islam, no conflict exists between the supreme authority of religion the definite and unquestionable status of divine laws and Islamic values - and the political status of people in an ideal Islamic state. As there are limitations for the will and desire of the people, they have authority within the framework of Islamic rules and values. Hence, a majority of the people or their representatives have no power to legislate or make judgments that contradict Islam.

At the same time the governors in an Islamic state must respect the rights, will, and authority of the people. Ayatollah Khomeini, the founder of the Islamic Republic of Iran during a meeting with the representative of Pope VI said:

"I do not want to impose (my will) on my people, and Islam does not permit us to establish a dictatorship. We follow our nation's votes and act according to their views. We have no right,
God has not conferred such a right to us, and the Prophet (PBUH) never permitted us to impose our ideas upon Muslims.”

Smoothing the Path to Religious Democracy the advocates of Islamic democracy usually refer to the shura (consultation) as the most important Islamic teaching that supports and justifies the authority of people in an Islamic government.

The Islamic government is one in which:

1. Supreme legislative authority is in accordance with the law of Islam called Shariah and scholars to deduce laws and regulations in details as a guideline for the judges.

2. The head of the Islamic state is the leader of the executive body assigned with the responsibility of implementing such laws and regulations.

3. Political power belongs to the community (Ummah), which should adopt a form of 'shura' which is a system of mandatory consultation.

4. Thinkers like Sadek Sulaiman maintain that shura in Islam includes basic elements of democracy. He says:

"As a concept and as a principle, shura in Islam does not differ from democracy. Both shura and democracy arise from the central consideration that collective deliberation is more likely to lead to a fair and sound result for the social good than individual preference".

The Holy Qur'an openly recommends and encourages that public affairs and the governance of the Ummah should be based upon Shura:

"And those who respond to their Lord and keep up prayer, and their rule is to take counsel amongst themselves. And ask pardon for them, and take counsel with them in the affair".

The second verse orders the Prophet (PBUH), who receives revelation and enjoys infallible 
knowledge, to take counsel with believers in management of public affairs. This command shows the fundamental significance of the participation of Muslims in social and political affairs. It is somewhat an exaggeration to suppose that the shura is the functional equivalent of western parliamentary democracy because there are some controversies amongst scholars about the political status of shura.

For instance, those who believe in the theory of Caliphate, emphasize that members of the council only have a duty to express their opinion with no right to make political decisions. Accordingly if the Caliph refers to the assembly to take their opinion regarding rulings, which he wants to adopt, their opinion is not binding on him, even if it is a consensus of majority opinion.

What makes shura one of the basic elements of Islamic democracy, it seems, is the fact that shura refers to one of the significant essentials of democracy. Democracy in its long history has had evolutions and alterations, but matters such as public participation, the rule of law and the responsibility and accountability of governors can be recognized as essential to democracy. In conclusion, but the question concerning the political role of consultation (Shura) in the process of making decisions still remains. Is consultation merely a religious duty of the ruler of the Islamic state, or is he bound by the decisions of those consulted?

The last verse of Surah Aale-Imran verifies the view that shura is not binding upon the ruler, for the Almighty God delegates the final decision, after consultation, to the Prophet (PBUH):

"And take counsel with them in the affair, so when you have decided then place your trust in Allah."

However, the practice of the Holy Prophet, according to some traditions, testifies that he had implemented and respected the opinion of the believers even when it was against his own views. It is recorded that the Prophet not only consulted with his experienced or close companions, but sometimes he held open meetings in which all Muslims were invited. The consultation that took place about the battle of Badr and Uhud was one such example. In the case of Uhud he gave example to the opinion of the majority of Muslims over his own concerning the location of the battlefield and decided to fight outside the city of Medina. He also consulted the people concerning the treatment of prisoners of war following the battles of Badr and al- Khandaq.

However, the Prophet did not consult the Muslims concerning religious affairs or divine matters. All of his consultations were restricted to war; peace and ordinary public affairs that were not determined by revelation and were not amongst the situations in which divine order determined must be done. For example, with regard to the treaty of al-Hudaybiyah the Prophet (PBUH) did not submit to the opinion of the majority of his companions who were in disagreement with the covenant, it was not in fact a consultation but a series of complaints made to the messenger regarding the terms of the peace. He rejected their suggestions to break his promises and continued to respect the agreement, which he had made because it was a command of Allah. He told them: "Verily I am the servant of Allah and his messenger. I shall never disobey his order."

In short, even though the shura in its historical function within the Islamic world does not totally overlap with the modern concept of democracy and the political status of parliament in contemporary representative democracies, it would be appropriate for shaping a limited democratic model for an Islamic state. (Hunter, 2005, p. 22)

The Qur'an emphasis on the status of shura as an essential aspect of the Islamic political 
system - according to those who interpret the word for amr in both of the two verses relating to shura, as referring to governmental affairs makes way for defining a determined systematic role for the people's representatives (members of the shura) within the body of the Islamic state. The above- mentioned verses are silent about how the form and mechanism of shura in an Islamic political system might be, consequently the constitutional approach inclines to determine and stabilize the political status of shura (people's authority) under the supreme authority of Islam does not confront any religious problem.

One of the most important characteristics of a democratic government is its accountability to its people. A democratic state must be accountable and its citizens must have the right to criticize its policies and functions. Advocates of religious democracy maintain that al-amrbi'lmarufwalnahy'an al-munkar (enjoining good and forbidding evil) is one of the most significant Islamic duties placed upon Muslims and it should render the Islamic state accountable. Many Quranic verses emphasize on this fundamental restriction, which if Muslims take seriously would produce a healthy and healthy society that is far removed from oppression, injustice and dictatorship. Almighty God says in the Holy Qur'an:

"And from amongst you there should be a party who invite to good and enjoin what is right and forbid the wrong, and these it is that shall be successful. And (as for) the believing men and believing women, they are guardians of each other, they enjoin good and forbid evil."

Islam made it obligatory for us to be concerned with the health and welfare of society, to oppose injustice and immorality, and to scrutinize the actions of those who undertake governmental affairs. There exists a mutual responsibility between the rulers and those whom they rule to implement and support the Islamic Shariah and this provides a clear framework and basis upon which citizens may question the actions and policies of their governors with regards to their socio-religious duties. As the most-noble Messenger (PBUH) in a famous tradition says:

"Every one of you is a shepherd (of the community), and all are responsible for their dependents and herd"

To perform this duty we need certain conditions to meet, such as the freedom of speech and to criticize as well as access to exact and objective information. Without freedom of speech and access to exact objective information constructive feedback and criticisms toward the governors and standing for justice and truth would be impossible. It is obvious that Islam unlike western culture disagrees with individual freedom. However, for Islamic and democratic government, Islam has already outlined the rights of the people and their contribution in socio-political affairs in Quran and Sunnah. For example the Qur'an encourages believers to listen to different opinions and to select the best of them:

\section{"Therefore give good news to my servant. Those who listen to the word then follow the best of it; those are whom Allah has guided, and those it is who men of understanding are."}

Imam Ali (AS), Once explained the mutual rights and duties that exist between an Imam (leader) and the people:

"It is your right that I must not hide any secret, except that of war, from you. And that I should not take over matters (without your consultation or awareness) other than those concerning divine laws."

Governments have always been ignoring the political teachings of Islam. The main purpose 
here is to show that these important teachings make the path even towards the establishment of a religious democracy. (Hunter, 2005, p. 34)

\section{Iranian Democracy}

For instance, constitutionalism and accountability in secular, western democracies as Nathan Brown says, has expressed itself most frequently in human authored constitutional texts and rights, whereas religious constitutionalism is defined under the authority of the Shariah. Therefore, the religious government is not only accountable with regard to people's rights and needs, but also with regard to the Shariah and divine laws.

After having viewed the characteristic of all these theories now we come to the Theodemocracy of Iran. According to the Western democracy sovereignty belongs to the people while according to the Iranian theo-democracy the eternal sovereignty belongs to Allah almighty and all the laws are made as per the teaching of Quran and Sunnah. The clear things which is viewed in the Iran Theo-democracy is that whole the Iranian political system is based on Quran and Sunnah and all the qualities which are found in other systems and other political theories, are found in excellent form in the Iranian Theodemocracy.

The power and authorities according to the western concept of democracy are delegated to the people while as per the Iranian Theodemocracy, all the power are secured from Allah Almighty, However these power are delegated provisionally to the people on the behalf Allah Almighty for which they will be answerable on the day of judgment. It's so seemed that Iranian theo- democracy is democratic values to their western concept of democracy of which a system is expected and then we see that later on in the sixteen century a church and state were detached.
A new theory secularism were presented and the West also had to introduce a new concept of democracy which was near to the Liberal concept of democracy. The characteristics existed in the Secularism and the Liberal democracy all are found in the Iranian Theo-democracy. There is a sound political system of Iran and as Iranian system believes in the internal sovereignty of Allah Almighty, equality of the people, satisfaction and contentment of the people and prosperity of the people, so we see all these things are deeply found in the democracy of Iran which we name the Theo democracy. Since a Theo-democracy is a system of government which proceeds state and religion parallel and we see these characteristics in the Theo -democracy of Iran, the Iran Theo democracy recognized code of rules and laws set forth by Islam.

An Iran is no doubt an emerging democracy and a central challenge for deepening democracy in the republic is how to effectively build the key institutions of democratic governance. A study of the political structure however indicates sufficient presence of these institutions on paper as depicted by: an independent electoral system, adequate separation of powers that should limit the powers of the President and even the Supreme Leader (Rehbar-e-Muazam) and an effective civilian control over the military and other security forces. However a thorough study of the political structure of Iran indicates theocratic governance, with the Supreme Leader (Rehbar-e-Muazam), who is not elected by popular votes by the way, principal everything. Another understandable dubiousness in Iran's 'democracy' is the absence of well-functioning political parties the absence of a free, energetic and independent media with strong dedication to professional ethics as media outlets are basically state-owned and regulated and the absence of a vibrant civil society, able to monitor government policies and to provide alternative forms of political participation. 
Apart from the obvious distinction between religious democracy and western liberal democracy, the former holds the same essential advantages as any democratic government. These include the participation of citizens, the distribution of political power by election, political accountability of governors, constitutionalism and political transparency as well as mutual responsibility between the rulers and the ruled. Religious democracy however, is far more desirable for Muslims than any feasible alternative because of the supreme role of the Shari'ah in providing a basis for, and shaping the growth of, the contents of this political system. It is also desired because of the qualities and moralreligious commitments that the governor must have as the leader of Muslim society.

After examined the model of democracy, Principal of democracy, kinds of democracy, merits and demerits democracy and future of democracy have been discussed in detail as under:-

\section{Evolution, Concept}

\section{and Structure of Iranian Democracy}

The power of Islam as it was 1400 years ago was based on true spirit of democracy for Muslims. In this perspective, Islam seems to be providing guiding through all the matters of life. Islam is the absolute solution to the entire problems faced by the humanity today. Thus Islam provides the Muslims guiding in the entire fields like economic, social, cultural and political. Islam takes the attention of the people with its different characteristic thus by prevailing justice. Islam brings the people in real and factual style. In revolutionary scene, ever presence of people and their contribution in all kinds of elections show the support and agreement on the Islamic style of democracy in Iran.

After the advent of Imam Khumeini in Iran, he introduced over there a true theo-dominant system and provided a complete code of life according to the true spirit of Islam. In the end, as per the fact and figures the deeds of Islamic revolution brought in Iran were sheerly due to Quran and Sunnah which may be a guide line for other Muslim societies. There are several countries of the world which are overwhelmingly dominated by any specific religion or faith, and the people of these countries want to develop their political system according to their own religion and faith. Iran is a first country which perfectly imposes it through democratic way. The greatest characteristic of Islamic revolution is its popularity over the people who accepted it due to its democratic aspect. The popularity of this revolution is different from other revolutions. First popularity is due to Islam.

This Iranian system is real model for the theo-dominant society. There is controlled democracy in Iranian political system. Iranian Guardian Council has a major roll in Iranian political system. Several Muslim countries are experiencing monarchy as well as dictatorship in their own folds. Even in the present age, the Muslim countries where monarchy is prevailed are Saudi Arabia, Qatar, Bahrain, United Arab Emirates, Yemen and Oman. And, Muslim countries where dictatorship exists are Syria and Sudan. These countries should adopt Iranian democratic system.

After studying and going through other system, It has been realized that the Islamic polity of Iran is the very systematic that can lead the other societies where is the religion is dominated. All the institutions of the Iranian political system have democratic behaviors and democratic functions. There is only a country in the world where an ideal religious democratic system in the shape of Majlis-eShoora is existed. And, there is regularization of presidential elections as well after specific tenure. Even during Iran-Iraq war of 1980-88, 
presidential elections had been held accordingly that show the strongest based of democracy in the Iran. Anti-revolution forces never wanted to see Iran as a strong democracy.

To weaken the spirit of the people and the administrative body who participated warmly in the revolution. The second presidential election of Iran held on May 1981, soon after the election anti-revolution force blown away the elected Majlis, as a rust of these sadistic incident 72 members of Majlis-e-Shoora including president Muhammad Rajai died at the spot. Even in these circumstances, Ayattulah Imam Khumeini issued his order for the re-president election in the country. Supreme Leader (Rehbar-e-Muazam) made untiring efforts regarding running the democratic process smoothly.

Iran adopted such Islamic democratic properties and formulated their own political system which is based upon pure democratic values. This newly system is called theodemocracy. According to this theo-democratic system of Iran which is working efficiently, has been described all in detailing chapter four and five.

The constitutional foundations of Islamic revolution of Iran are based upon oneness of Allah. Allah is the supreme commander of this universe. All the authorities and greatness belong to Him. Allah has given authority to men on these universes considering him. His successor and every authoritative will be answerable before Allah in the Day of Judgment. Allah sent Hazrat Muhammad (PBUH) and his last prophet and gave him the holy Devein book Quran majeed.

This Divine book has all the rules and regulation for spending a peaceful life on earth. All these Quranic rules and regulation can be seen practically in Islamic Republic of Iran, after Islamic revolution. When we see this Islamic rule in Iran politically and constitutional prospective, we conclude that Islam and democratic rules are basically same. There is no fundamental different between the two.

It is among the golden principal of democracy that the elected members should be pious educated and should have vast national and international understanding about various problem. In present political system of Iran such qualities, selection and election of Supreme Leader (Rehbar-eMuazam), president and Majlis-e-Shoora, shows the democratic values.

After coming to power, the Islamist power led by Ayatollah Khumeini introduced to the world new Islamic democratic government. In this government, every segment of the state and Iranian society was provided an opportunity to become a part of the mainstream of Iranian masses, Ulema, religious Leaders, army, and civilian administration reconciled with one another and became part and parcel for this government. Following are the salient features of this Islamic constitutional democratic government. In Introduction to Iranian Political System we can say that, Although Iranian political structure is a democratic system, it may seem different from other parallel democratic systems. The origin and the roots of the Iranian political system have such uniqueness that they are beyond reason.

The political system of Islamic Republic of Iran is the outcome of the Islamic Revolution of 1979, the first of its type in the whole world. Therefore, Iranian political system established afterward should have been defined according to the ideals of such a revolution. In this political system, the structure of power will be dealt with to find out whether who is whom in the Republic. Iranian political structure can be realized if we look at it as two sections: Iranian government, which works according to Iranian Islamic Constitution, and other political entities that helps in the formation of the complete political structure. More importantly, the Supreme Leader 
(Rehbar-e-Muazam), who is the highest authority in the Iran, and Guardian of the whole system.

Even in the selection of spiritual leader, they play an important role despite the fact that spiritual leader is divine rank and depends on the will of Allah and is a spiritual occupation. As in Iran, leadership expert hold a meeting of representative of the people who are also member Majlis-e-Shoora and select a particular person. If selected person is rejected by the people, the leader will not be selected.

Majlis Shoora we should have glance how member of Majlis-e-Shoora are elected. People participate in election and through free and fair election process member are elected. In this process minorities are also given full chance of representativeness.

Majlis-e-Shoora makes law for the solution of political social religious and economical problems of the country. So, in accordance with the democratic values observance of human rights can be seen clearly that minorities are given due respect and status in Islamic Republic of Iran.

Other revolution which were really revolution after victory has rejected people Legislative parliament where representative of republic are selected and no one has right to impose any person on public. Out of 290 members of parliament there is not a single deputy who came without the selection of people.

Election for president is held after four years in Islam Republic of Iran. People directly cast their vote to elect their president, people of Iran have democratic, their thinking and caste vote according to their wishes. Generally people elect such personality as their president which has wider outlook and graft over nation and international issues. In Iran president election comes after every four year and only twice a candidate is even a chance to work at this eminent position of president, these election are true reflection of democracy and all democratic values. People cast their vote independently in free and fair election. not only this but election result are mostly acceptable most of the Iranian. losing party generally accepts all election results and show complete democratic behaviour. President is answerable before the Supreme Leader (Rehbare-Muazam) Majlis-e-Shoora and public.

President, who is the leader of executive and the incharge of the activities of country, is also elected through the direct vote of the people. And, this selection is their own personal opinion. On the other hand in western style of democracy, the selection of the president is not the same as in Iran where parties in front of each other's and select their representatives. People cast their vote for the party in the west, but in Iran, people directly know about the candidates who are being participated in the political affairs like elections.

Judiciary play an important role for the progress and welfare of the society. Decision by judiciary plays a vital role and it increase level of confidence of the people on judiciary system. In judiciary, all judges should be just and equally based in Iranian Islamic system. Judiciary is free so that it may give decision according to law without any pressure, besides this supply of basic rights to public in the obligation of judiciary. In Iran, specially considered that minorities should enjoy their full judicial right in Iranian citizen.

In Iran, every effort is put to make the democracy run smoothly. For this purpose people are given full authority and liberty to choose the members of Majlis-e-Shoora in transparent elections which are held after every four years on regular bases. Not only presidential government system is running smoothly with great success but Local government system is also functional since 1999. The success of this system also reflects that democratic values are given major importance by Iranian system.

The democratic republic of Iran has been a successful democracy which is an illustration 
throughout the world. The great revolution of 1979 , it can be strongly argued that the democratic values have ever helped flourish democracy in the Islamic Republic of Iran before and after revolution. The following election results from 1980 to latest, 2009 are the ample evidence of this claim. The up-coming presidential elections of June 2013 are also expected to further strengthen democracy in the country

Before the formation of Islamic republic of Iran all the officers and authorities were appointed on the basis of social status rather than the merit But today all the member of the judiciary, Majlise-Shoora as well as executive are elected through the vote of the masses, even the election of the spiritual leader, When we analyze the system of Iran we find no hint of any rebellion or revolt against this system because there has been complete harmony and pacification in it.

It is because of this that there have never a military coup like that in other third world countries, so, all this is the ample proof of this success of the Theo democracy of the Islamic republic of Iran.

In different parts of world revolution was brought about by the people but after victory and when they are attain the successor and different parties has taken its place and rejected people in the same way in socialist and communist countries where new style are produce by revolutionary system. The people play a best role in revolution, then war groups came under power and authority. But in their countries where the revolution got success no rights are given to the people. And party has snatched all the rights even they have no authority then they have select in single Member of Parliament. In these countries there is not a single so called public representative origination, and from legislative point too there is no representative of public. But in Iran revolution has changed every matter and gave a democratic way out.

In this sense, the Theo-democratic system of Iran is working successfully. As the democratic system of Iran is the best one and has many qualities and characteristic which a democratic system should have. It is oblivious that all the people keep devotion with their sects or religious weather they are Christens, Jews, Muslim or Hindus. The task of the state is to regulate and keep moderate the inclination towards the religious moderation. The Islamic Theo-democratic of Iran is an ideal republic and is guiding star for whole Theo- dominant societies of the world.

During analyzing findings of the research, it has been realized that the role of Guardian Council has been authoritative. Similarly, Chief Justice is appointed not on the merit, but on the will of Supreme Leader (Rehbar-e-Muazam). So, we have to recommend that there should be a co-operation among Majlis-e-Shoora and the Guardian Council. Similarly, Chief Justice of Iran should be appointed on merit.

This time, Iran is experiencing a successful governing system which is respecting public opinion as well as electing candidates on merit without exploitation of any sect or religious community. Even, there is majority of Shia population, but Iran democracy is fully facilitating followers of Sunni sect of Islam, Zoroaster and Jewish community on parallel basis. So, we can conclude that this governing structure can be experienced successfully in all the theocratic societies of the world.

\section{References}

1. Chany, E. (2011). Democrtic Change in the Arab World. Brooking PDF, 12-13.

2. Dr.Anup Kumar, P. C. (1985). A Comprehensive Study of Political Science Theory. New Dehli: Good Will Publisher. 
3. F. Gaus, G. (2000). Poltical Concept and Political Theories. New York: Westview Press.

4. Haque, M. u. (1994). Political science Theories and Practice. Lahore: Bookland (PVT)LTD Lahore.

5. Hunter, S. T. (2005). Modenization,Democracy, and Islam. London: Greenwood Publisher.

6. Ismeal, T. Y. (1991). Government and Politices in Islam. New Dehli: S.K.Jain for CBS Publisher.

7. K.Rai, H. (2000). History of the Political Philosopy. Lahore: Aziz Publisher Urdu Bazar Lahore.

8. Micel, M. C. (2003). Theocracy. For presentation at the ASREC conference in Washington, $D C, 24$.

9. Mouhammad, S. (1994). Introduction of Political Science. Lahore: Ilmi Kitab Kana Urdu Bazar Lahore.

10. Robert, D. (2000). On Democracy. New York: Yale University Press.

11. Ross, A. (1952). Why Democracy. Landon: Harved University Press.

12. W.Y. Elliot. (1949). Western Political Hiritage. New York: Hall Publisher.

\title{
Теократическая демократия:
}

\section{исследование на примере политической системы Ирана}

\author{
Сайед Рахим Аббаса \\ ${ }^{a}$ Колледж Баккара \\ Пакистан \\ ${ }^{6}$ Колледж Асгар Молл, Равалпинди \\ Пакистан
}

\begin{abstract}
Демократия является предпочтительным популярным типом управления обществом по всему миру. Демократия подразделяется на несколько типов в зависимости от своей природы и демографической среды. В теократических обществах демократия является предметом многочисленных споров. В то время как для Европы роль иеркви в управлении больше не имеет большого значения, мусульманам требуется управление по законам Ислама. Тем не менее основной проблемой является то, что каждая иерковь определяет исламскую политическую систему по-своему.

В данной статье представлено определение и история демократии, ее типы и роль, которую она играет в теократических обществах. Авторы статьи рассуждают о христианских и исламских обществах. Политическая система Ирана, которая представляет собой современную демократическую систему в рамках теократической структуры, исследуется 6 качестве примера демократии, успешно реализуемой со времен Революиии 1979 г.
\end{abstract}

Ключевые слова: иура, рахбар-е-муазам, сунна, иариат.

Научная специальность: 23.00.00 - политология. 